J-DEPACE, Volume 4, Nomor 1, Juni 2021, Hal 31-38

Tersedia online di :http://jurnal.lpmiunvic.ac.id/index.php/jpkm

\title{
PEMANFAATAN LIMBAH TANAMAN JAGUNG SEBAGAI PAKAN TERNAK PADA KELOMPOK TANI TERNAK (KTT) ABIMANYU 1 KELURAHAN KLAMALU DISTRIK MARIAT KABUPATEN SORONG
}

\author{
Charliany Hetharia ${ }^{1 *}$, Lanny Wattimena ${ }^{2}$ \\ Yerrynaldo Loppies ${ }^{3}$, Wiesje Ferdinandus ${ }^{4}$ \\ Universitas Victory Sorong \\ 1 janethnadin270416@gmail.com *, ${ }^{2}$ lannywattimena@gmail.com, \\ ${ }^{3}$ jhay.loppies@gmail.com , ${ }^{4}$ wiesjeferdinandus@gmail.com
}

\begin{abstract}
ABSTRAK
Kegiatan pengabdian ini dilaksanakan selama dua bulan, dari bulan Maret sampai dengan April 2021 pada Kelompok Tani Ternak Abimanyu 1 yang berada di Kelurahan Klamalu Distrik Mariat Kabupaten Sorong. Kelompok tani ternak Abimanyu merupakan salah satu mitra pengabdian yang beranggotakan 12 orang petani peternak. Bahan yang digunakan dalam pengabdian ini adalah limbah tanaman jagung sebagai bahan utama serta EM4, dedak padi dan molases sebagai bahan tambahan. Alat yang digunakan pada kegiatan pengabdian ini adalah mesin pencacah, drum plastik, terpal dan karet sebagai tali. Hasil dicapai dari kegiatan pengabdian ini adalah KTT Abimanyu 1 dapat memahami permasalahan pakan ternak dan penanggulangganya dengan memanfaatkan limbah tanaman jagung, serta dapat membuat fermentasi pakan ternak dari limbah tanaman jagung.
\end{abstract}

Kata kunci: limbah, tanaman, jagung, pakan 


\section{ABSTRACT}

This service activity was carried out for two months, from March to April 2021 at the Abimanyu 1 Livestock Farmer Group located in Klamalu Village, Mariat District, Sorong Regency. The Abimanyu 1 cattle farmer group is one of the service partners consisting of 12 breeder farmers. The materials used in this service are corn plant waste as the main ingredient and EM4, rice bran and molasses as additional ingredients. The tools used in this service activity are chopping machines, plastic drums, tarpaulins and rubber as ropes. The result achieved from this service activity is that the Abimanyu 1 Summit can understand the problem of animal feed and its management by utilizing corn plant waste, and can make animal feed fermentation from corn plant waste.

Keywords: waste, plants, corn, feed

\section{PENDAHULUAN}

Sistem pemeliharaan ternak sapi di Indonesia sekitar $80 \%$ masih diusahakan oleh petani kecil yang berkembang di beberapa wilayah pedesaan (Winarso, 2010). Usaha pemeliharaan ternak sapi dalam skala kecil dapat membantu perekonomian petani di pedesaan dengan memanfaatkan sumberdaya alam yang tersedia di sekitarnya. Sapi mempunyai beberapa keunggulan diantaranya membutuhkan modal usaha yang relatif kecil, mudah memeliharanya, mudah menjualnya dan banyak digunakan sebagai bahan-bahan kuliner seperti redang, abon, dam bakso. Selain itu, berbagai acara keperluan keluarga seperti tasyakuran maupun acara lainnya yang berhubungan dengan ritual keagamaan seperti hewan qurban pada hari raya keagamaan dan aqiqah juga menggunakan hewan sapi (Rusdiana \& Sutedi, 2014).

Selain ternak sapi, sapi merupakan salah satu dari lima komoditas yang menjadi konsentrasi utama pembangunan pertanian selain padi, jagung, kedelai, dan gula tebu. Sehingga Kementerian Pertanian masih mencanangkan upaya swasembada daging sapi dan kerbau. Oleh karena itu, upaya untuk mendukung pembangunan peternakan sapi dari aspek pakan perlu dilakukan. Mayoritas masyarakat pedesaan di Indonesia berprofesi sebagai petani, dan mempunyai banyak limbah pertanian. Pemanfaatan limbah pertanian, seperti jagung berupa pelepah jagung dan batang jagung, jerami kacang tanah, rumput, dan dedaunan sebagai pakan basah merupakan upaya yang dapat dilakukan untuk meningkatkan efisiensi usaha, yaitu dengan menekan biaya pakan (Suwignyo dkk., 2016). 
Kabupaten Sorong merupakan kabupaten di Propinsi Papua Barat sebagai sumber penghasil ternak sapi dan tanaman Palawija salah satu diantara tanaman jagung. Sebagai salah satu sentra produksi jagung memiliki peran yang sangat besar dalam menunjang ketahanan pangan nasional. Luas panen jagung pada Tahun 2015 mencapai 430 Ha dengan produksi 740 ton dengan produktifitas rata-rata sekitar $17.21 \mathrm{kw} / \mathrm{Ha}$. Pada umumnya tanaman jagung hanya yang dimanfaatkan adalah biji jagungnya yang diambil. Sedangkan bagian lain dari tanaman ini berupa jerami, tongkol dan klobot atau kulit jagung yang jumlahnya cukup banyak. Sebanyak 20 - $30 \%$ dari 100 kg jagung adalah limbah jagung (BPS, Kabupaten Sorong 2015)
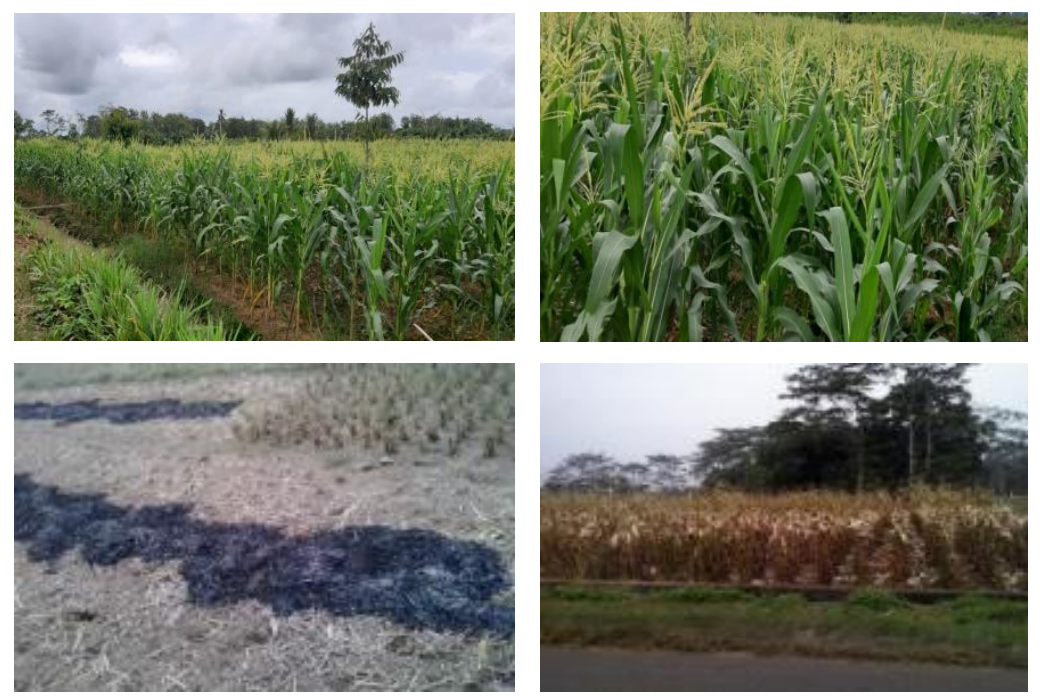

Gambar 1. Limbah Tanaman Jagung yang tidak dimanfaatkan

Kelurahan Klamalu Distrik Mariat Kabupaten Sorong mayoritas warganya adalah petani peternak sapi dan jagung. Namun sebagai usaha sampingan untuk pemenuhan kebutuhan, selain bertani mereka juga memelihara ternak berupa sapi dan kambing. Namun keluhan warga dalam beternak adalah masalah pakan ternak yang tidak menentu. Di musim penghujan pemenuhan kebutuhan pakan ternak memang tercukupi, namun tidak sama halnya ketika musim kemarau. Sebenarnya potensi bahan pakan untuk ternak di keluarahan Klamalu sangat melimpah. Situasi ini terjadi ketika musim panen padi dan jagung. Limbah sisa pertanian seperti pelepah jerami, tongkol dan klobot atau kulit jagung, pelepah pohon jagung dibakar untuk persiapan lahan tanam selanjutnya. Kurangnya pemanfaatan jerami, tongkol dan klobot atau kulit jagung sebagai salah satu bahan pakan ternak yaitu kandungan serat kasar tinggi dan protein serta kecernaan yang rendah. Penggunaan limbah tanamanan jagung secara langsung sebagai pakan tunggal tidak dapat 
memenuhi pasokan nutrisi yang dibutuhkan ternak. Untuk dapat memanfaatkan limbah yang berlimpah maka perlu dilakukan suatu upaya peningkatan daya guna dari limbah tersebut melalui suatu teknologi pakan yang tepat guna. Salah satu teknologi pakan tepat guna yang dilakukan dalam pengolahan bahan pakan ternak adalah bioteknologi melalui fermentasi (Afandi, 2014). Tentu ini merupakan potensi yang baik untuk dapat memenuhi kebutuhan pakan ternak apabila limbah tanaman jagung berupa, tongkol dan klobot atau kulit jagung tersebut diolah melalui proses fermentasi menjadi silase. Sehingga petani tidak akan mengalami kesulitan pakan ternak saat musim kemarau. Namun pemasalahannya adalah masyarakat tidak memahami bagaimana cara memanfaatkan potensi tersebut sebagai pemenuhan kebutuhan pakan.

\section{MASALAH}

Permasalahan yang dihadapi oleh kelompok Tani Ternak Abimanyu 1 adalah kurangnya penyediaan stock pakan ternak pada musim kemarau sehingga dibutuhkan teknologi untuk pembuatan silase sebagai pakan ternak menggunakan limbah tanaman jagung. Untuk itu proses pembuatan pakan ternak dengan menggunakan teknologi tepat Guna melalui pembuatan silase berbahan baku limbah tanaman jagung dan bagaimana ketersedian alat pencacah bahan pakan.

\section{METODE PELAKSANAAN}

\subsection{Waktu dan Tempat Kegiatan}

Kegiatan pengabdian ini dilaksanakan selama dua bulan, dari bulan Maret sampai dengan April 2021 pada Kelompok Tani Ternak Abimanyu 1 yang berada di Kelurahan Klamalu Distrik Mariat Kabupaten Sorong. Kelompok tani ternak Abimanyu merupakan salah satu mitra pengabdian yang beranggotakan 12 orang petani peternak.

\subsection{Alat dan bahan}

Bahan yang digunakan dalam pengabdian ini adalah limbah tanaman jagung sebagai bahan utama serta EM4, dedang padi dan molases sebagai bahan tambahan. Alat yang digunakan pada kegiatan pengabdian ini adalah mesin pencacah, drum plastik, terpal dan karet sebagai tali. 


\subsection{Pelaksanaan Kegiatan}

Adapun tahapan yang dilaksanakan dalam pengabdian ini adalah sebagai berikut :

1. Mengadakan observasi atau survei untuk mengetahui kondisi Kelompok tani ternak Abimanyu 1 Kelurahan Klamalu Distrik Mariat Kabupaten Sorong. Dari hasil observasi atau survey yang dilaksanakan maka dibuatlah jadwal untuk penyuluhan serta pelatihan dan pembuatan silase pakan ternak dari limbah tanamn jagung.

2. Mengidentifikasi masalah yang dihadapi oleh Kelompok tani ternak Abimanyu 1 melalui wawancara yang dilakukan. Permasalahan yang dihadapi oleh kelompok tani ternak Abimanyu 1 adalah pemenuhan pakan ternak selama musim kemarau.

3. Melakukan pelatihan dan pembuatan silase pakan ternak dari limbah tanaman jagung. Kegiatan ini diawali dengan persiapan limbah tanaman jagung sebagai bahan utama pakan, dilanjutkan dengan persiapan bahan tambahan dan alat yang akan digunakan dalam pebuatan silase tersebut. Tujuan dari pembuatan pakan ternak ini adalah untuk mengetahui fermentasi pakan ternak sehingga bisa membuatnya sendiri guna pemenuhan kebutuhan pakan ternak.
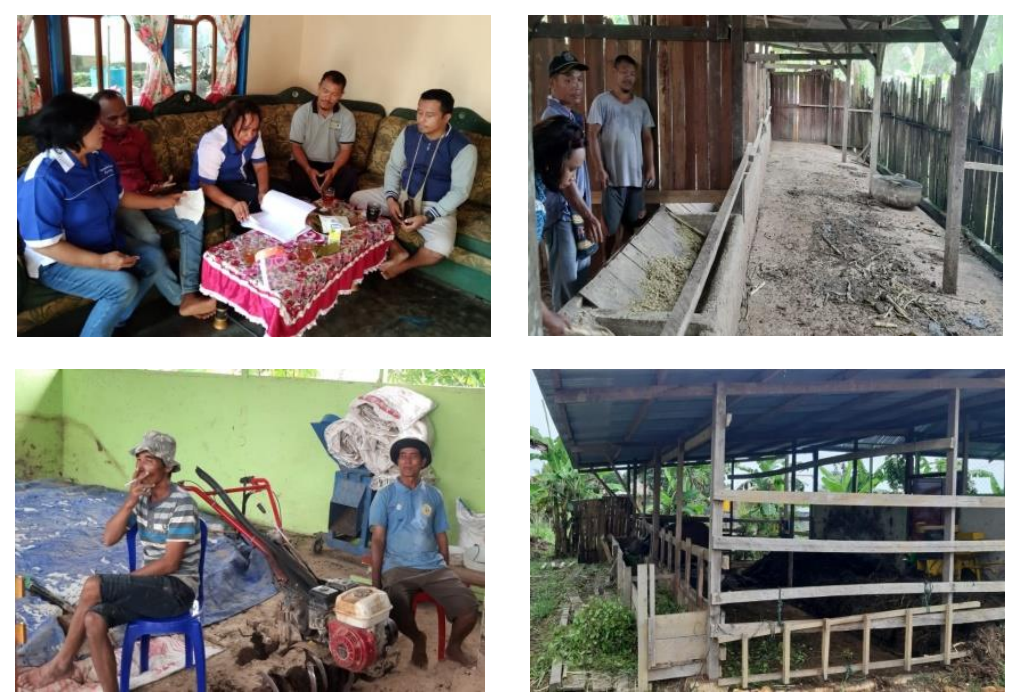

Gambar 2. Tahapan Pelaksanaan Kegiatan 


\section{HASIL DAN PEMBAHASAN}

Hasil yang dicapai dari kegiatan pengabdian ini adalah KTT Abimanyu 1 dapat memahami permasalahan pakan ternak dan penanggulangganya dengan memanfaatkan limbah tanaman jagung, serta dapat membuat fermentasi pakan ternak dari limbah tersebut.
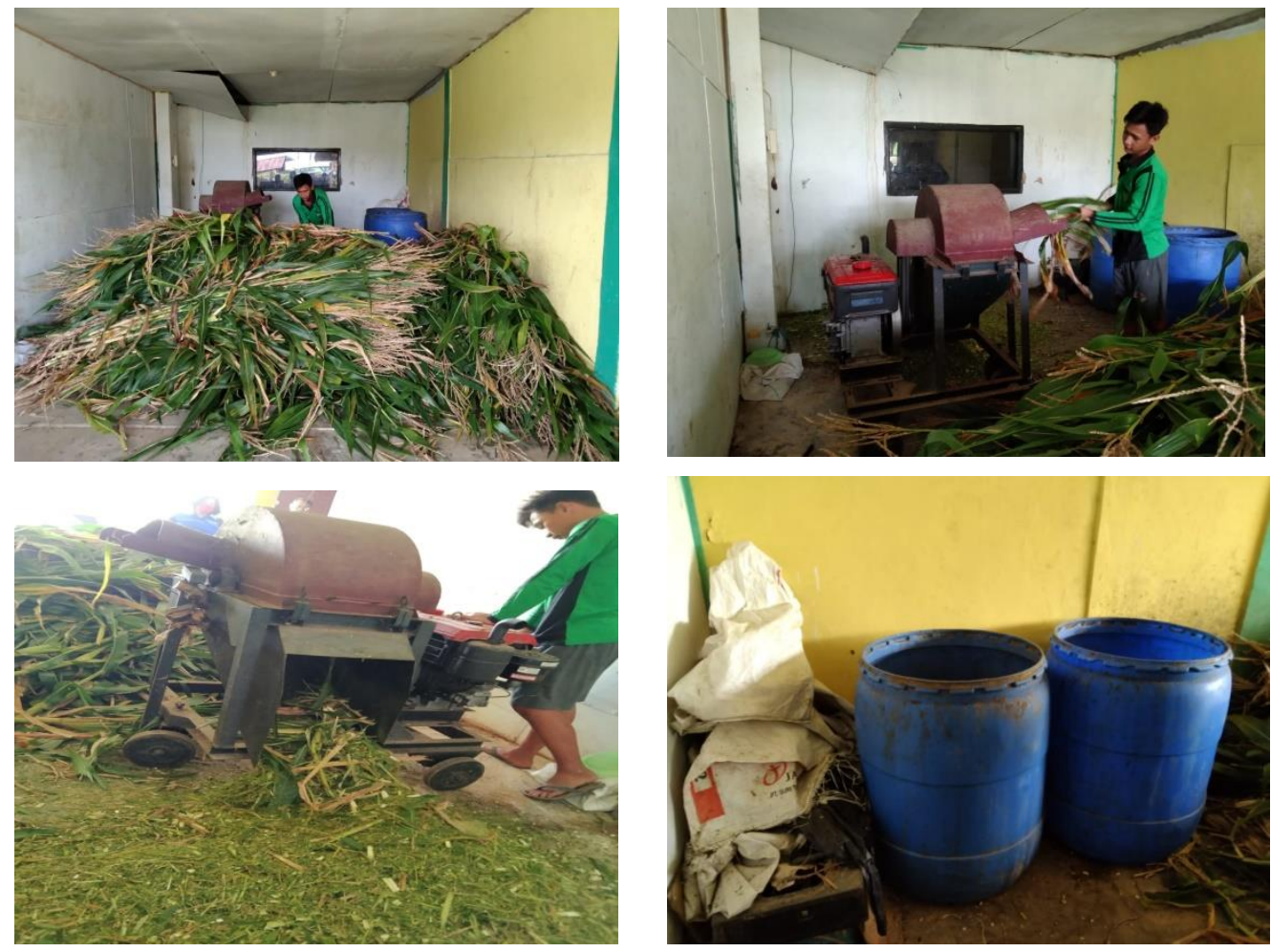

Gambar 3. Proses Pembuatan Silase

Pemanfaatan limbah tanaman jagung yang melimpah sebagai pakan ternak melalui pembuatan silase, memberikan solusi yang tepat bagi peternak sapi atau ruminansia lainnya karena dapat menjamin ketersediaan pakan saat musim kemarau. Menurut Bolsen dan Sapienza dalam Marlina dkk (2019), Silase merupakan pakan ternak yang dihasilkan melalui proses fermentasi hijauan yang mengandung kadar air tinggi. Melalui pembuatan silase, limbah tanaman jagung yang digunakan sebagai hjauan akan mengalami perombakan komponen makro menjadi komponen mikro yang lebih sederhana, sehinga mudah dicerna oleh mikroba rumen dan dapat meningkatkan daya cerna serta efisiensi pakannya (Sutanto, 2000).

Penambahan bahan tambahan lainnya dimungkinkan dalam pembuatan silase. Secara umum, yang dimaksud dengan bahan tambahan lainnya dalam pembuatan silase adalah bahan yang dapat membantu proses ensilase, dalam mensuplai nutrien bagi bakteri asam laktat untuk memproduksi asam laktat (Marlina dkk, 2019). Menurut Marlina dkk (2019), enzim atau mikroba dapat meningkatkan ketersediaan nutrisi yang dibutuhkan bakteri pembentuk asam laktat. 
Hijauan yang diperoleh berasal dari limbah tanaman jagung. Jerami jagung dicacah menggunakan mesin pencacah untuk mendapat hasil cacahan yang lenih kecil dengan ukuran yang sama. Proses pembuatan silase selama 1-2 minggu, selanjutnya silase disimpan sebagai cadangan pakan ternak untuk musim kemarau dengan kondisi tertutup rapat (anaerob). Tujuan pembuatan silase adalah untuk pemanfaatan limbah tanaman jagung sebagai hijauan untuk pakan ternak disaat produksi jagung melimpah sehingga limbahnya dapat diawetkan dan digunakan pada saat produksi hijauan rendah (kemarau).

Bahan tambahan yang ditambahkan sekitar $0,5 \%$ dari berat hijauan yang akan diolah. Hijauan yang telah dicacah disusun dalam silo yang terbuat dari tong plastik yang didesain khusus sebagai silo. Menurut Marlina dkk (2019), proses penumpukan hijauan dalam silo harus betul-betul padat sehingga tidak ada udara yang bertahan di sela-sela tumpukan. Setelah 2 minggu massa inkubasi anaerob, silase sudah menunjukkan kematangan dengan ciri-ciri yaitu warna hijau kecoklatan, bau aroma asam segar, tekstur padat, tidak lembek dan tidak berlendir, dan pH 4,3 (Kung dan Shaver, 2001).

Pada saat uji coba pemberian silase kepada ternak sapi sebagai pakan ternak, terlihat dari ternak sapi dengan cepat mengkonsumsi silase. Hal ini selajan dengan pengabdian Marlina dkk (2019) yang juga melihat respon ternak domba yang cepat mengkonsumsi silase yang terbuat dari limbah tanaman jagung dan jerami padi.

\section{KESIMPULAN}

Kelompok tani ternak Abimanyu 1 dapat membuat fermentasi pakan ternak (silase) dengan memanfaatkan limbah tanaman jagung sehingga permasalahan pakan dan penanggulangannya dapat terselesaikan dengan baik.

\section{DAFTAR PUSTAKA}

Afandi. 2014. Nilai Nutrisi Silase Pakan Komplit Berbahan Dasar Jerami Padi Dan Biomassa Murbei. Makassar: Universitas Hasanuddin.

Budiyanto, E., Yusuf. Amran. 2018. Pemanfaatan Limbah Pertanian Sebagai Pemenuhan Kebutuhan Pakan Ternak Ruminansia Di Desa Rukti Endah Kecamatan Seputih Raman Kabupaten Lampung Tengah. SAKAI SAMBAYAN-Jurnal Pengabdian kepada Masyarakat Vol 2 No 3 hal 109-113

Marlina, E.T., Deden Z. Badruzzaman dan H. Setiyatwan. 2019. Aplikasi Limbah Ternak Sebagai Sumber Mikroba Untuk Fermentasi Silase Dikelompok Tani Rancamulya Sumedang. Dharmakarya: Jurnal Aplikasi Ipteks untuk Masyarakat. Volm 8. No2 : Hal $119-123$ 
Naifa, R., R, O., B, N. T., \& Detha, A. A. 2015. Kualitas Nutrisi Silase Rumput Gajah (Pennisetum purpureum) yang Diberi Dedak Padi dan Jagung Giling dengan Level Berbeda. Journal of Animal Science Vol. 1 No. 1, hal. 68.

Rusdiana, S., \& Sutedi, E. 2014. Analisis Produksi Rumput Brachiaria Dalam Pengembangan Usaha Ternak Kambing. Jurnal Peternakan Vol 11 No 2, hal. 69 - 77.

Subekti, E. 2009. Ketahanan Pakan Ternak Indonesia. MEDIAGRO VO

Sutanto, H. 2000. Masalah Gizi dan Produktivitas Ternak Ruminansia di Indonesia. Universitas Brawijaya

Susilo, D. D., Widodo, P. J., \& Ubaidillah. (2012, September). Mekanisasi Proses Pencacahan Bahan Pakan Ternak dalam Pembuatan Pakan Ternak Fermentasi. MEKANIKA VOL. 11 NO. 1, hal. 31-36.

Winarso, B. (2010). Prospek dan kendala pengembangan agribisnis ternak kambing dan domba di Indonesia. Peningakatan Daya Saing Agribisnis Berorientasi Kesejahteraan Petani, (hal. 246-264). Pusat Analisis Soasial Ekonomi dan Kebijakan Pertanian Kementrian Pertanian. 